\title{
The Effect of Public Support on College Attainment
}

\author{
Philip A. Trostel \\ Correspondence: Philip Trostel, Margaret Chase Smith Policy Center \& School of Economics, University of \\ Maine, Orono ME, 04469-5784, U.S.A. Tel: 1-207-581-1651. E-mail: philip.trostel@maine.edu
}

Received: September 22, 2012 Accepted: October 24, 2012 Online Published: November 28, 2012

doi:10.5539/hes.v2n4p58 URL: http://dx.doi.org/10.5539/hes.v2n4p58

The research was partially financed by the Wisconsin Center for the Advancement of Postsecondary Education, University of Wisconsin - Madison

\begin{abstract}
This study estimates the extent that state financial support for higher education raises college attainment. Despite its manifest importance for policy, this is the first study to estimate this effect directly. Many studies have estimated the effect of college price on attendance, but state support for higher education and college price do not have a one-to-one correspondence. Moreover, state support for higher education can affect enrollment through college quality, not just price. A two-stage instrumental-variables approach is employed to account for the possibility that state funding for higher education may endogenously depend on anticipated college enrollment. Using 22 years of U.S. interstate data (1985-2006) and controlling for fixed state effects, the results of this study indicate that state funding for higher education has significant causal effects on both college enrollment and degree attainment. The estimated state-support elasticity of college enrollment and college degree attainment is about 0.35 .
\end{abstract}

Keywords: college funding, education attainment, degree attainment, student response, college price

\section{Introduction}

Various levels of government in the U.S. spend more than $\$ 100$ billion annually (one percent of national income) on tertiary education (according to the U.S. National Income and Product Accounts). Presumably the main reason for this substantial public expenditure is that it leads to significantly greater college attainment.Yet, there is almost no research quantifying this effect.Numerous studies have estimated the student response to net tuition and fees [this literature is surveyed by Leslie and Brinkman (1987), Heller (1997), and Deming and Dynarski (2009)], but not the response to public support for tertiary education.Although public funding for tertiary education can obviously reduce the net price that students must pay for a college education, the relationship is not one-to-one. Indeed, the relationship between state spending government spending for higher education and net tuition and fees at public colleges is far from inversely proportionate. Koshal and Koshal (2000) estimate that each dollar of state postsecondary education funding per student reduces the net price by only about 40 cents. This finding is confirmed more recently in Titus et al. (2010), which finds the effect to be closer to 20 percent.

Public funding for tertiary education can affect college quality and amenities (i.e., education resources per student) as well as net price. Not all college educations are equal.And economic decisions are clearly about value (i.e., quality relative to price), not just price. The cheapest product is often not the best value. Consequently, public support for higher education can affect college attendance and completion without necessarily affecting the net price.Thus, estimates of the price response of college enrollment or attainment are not necessarily the same as the response to public funding.Moreover, from a policy perspective, perhaps the more pertinent question is about the student response to public funding rather than the average response to net tuition and fees.

Berger and Kostal (2002) and Bound and Turner (2007) also contend, and provide empirical evidence, that resources per student matter for college attainment.Indeed, these studies are the closest in spirit to the present study (Note 1). Although neither study directly estimates the effect of state funding for tertiary education on college attainment, their results suggest that the effects on college attainment are different for public funding and net price.But the results on this issue are somewhat conflicting. Berger and Kostal (2002) find that the enrollment effect from public funding is noticeably smaller than the effect of tuition, while Bound and Turner's (2007) results indicate the opposite. Bound and Turner's results suggest apublic-support attainment elasticity of 
bachelor's degree attainment of about one (Note 2), which is greater than most estimates of the tuition elasticity of college enrollment, particularly the more recent estimates [see, e.g., Leslie and Brinkman (1987), Heller (1997), and Deming and Dynarski (2009)].

Thus, an important unanswered policy question is how much college attainment is bought with public investment in higher education. This study attempts to answer this question using U.S. state-level data from 1985 through 2006. The effects of public funding for higher education are estimated for both college enrollment and degree attainment. More specifically, this study estimates the effect of state- and local-government funding for postsecondary education per potential college student (high school graduates from the previous four years) on enrollment per potential college student, and the effect of state- and local-government funding for postsecondary education per potential college graduate (high school graduates four years earlier) on degrees per potential college graduate. The analysis of thepanel data allows for fixed state effects and controls for per capita income, average college attainment, and the trend over time.As state funding for higher education could endogenously depend on the number of students enrolled in public higher education, a two-stage instrumental variables approach is used to estimate the causal effect of state higher education spending on college enrollment and degree attainment. Specifically, state- and local-government tax revenuesand K-12 expenditures are used as instruments for state- and local-government funding for postsecondary education.

\section{Econometric Models}

Arguably the most important measurable college outcome is enrollment.In recent years, however, as there has been an increasing emphasis on improving accountability in higher education, the focus has increasingly been on degree attainment rather than enrollment. There is considerable evidence, though, that it is time spent in education, as opposed to necessarily earning degrees, that drives labor-market outcomes such as higher earnings, lower unemployment, etc. (Note 3). This suggests that it is appropriate to emphasize students being in college. Moreover, estimating the effect on enrollment is slightly more straightforward than the effect on degree attainment (because degrees take multiple years to earn and there are different types of degrees). Bound and Turner (2007), however, prefer to emphasize the degree completion.In any event, the effects of state funding for higher education on both enrollment and attainment are estimated.

In the case of enrollment, the dependent variable is full-time equivalent college enrollment in public postsecondary institutions $\left(E_{k, t}\right.$, where $k$ denotes the state and $t$ denotes theacademic year) per potential college student, and potential college students are measured as high school graduates in the preceding four years $\left(\sum_{s=t-4}^{t-1} G_{k, s}\right)$. For enrollment levels to be comparable across states and time, they are relative to their potential enrollment levels (Note 4). Using high school graduates in the state in the previous four years as the measure of potential college enrollment in public colleges clearly places the emphasis on 'traditional' college students (i.e., those progressing straight from high school to college). About two thirds of all college freshmen enroll directly out of high school (Note 5). The ratio of enrollment to potential enrollment can be greater than 100 percent because graduate students are included in the full-time-equivalent enrollment measure and because some states are net attracters of college students from other states and abroad.All enrollment, and not just baccalaureate or undergraduate enrollment, is used because the independent variable of interest, state- and local-government postsecondary education funding, is applicable to all enrollment.Public funding for postsecondary education is not assigned by degree level. To best quantify the relationship between funding and college enrollment thus requires including all enrollment (Note 6).

The important independent variable here is state- and local-government appropriations for postsecondary education $\left(S_{k, t}\right)$ per potential college student (high school graduates in the preceding four years). For state funding levels to be comparable across states and time, they are made relative to their funding need.Per capita income $\left(I_{k, t}\right)$ is included as an additional control variable to account for interstate differences in the ability to pay for college (and also interstate differences in the cost of providing college education). The percentage of the state's population within the ages of 35 to 64 with at least a bachelor's degree $\left(\mathrm{A}_{k, t}\right)$ is included as another control variable to account for interstate differences in parental college attainment.The regressions also include observation year to capture the trend over time. Finally, because there is a minimum of control variables, the regressions allow for fixed effects for each state $\left(d_{k}\right)$. Thus, the enrollment equation to be estimated is

$$
E_{k, t} / \sum^{t-1}{ }_{s=t-4} G_{k, s}=\mathrm{f}\left(S_{k, t} / \sum^{t-1}{ }_{s=t-4} G_{k, s}, I_{k, t}, \mathrm{~A}_{k, t}, t, d_{k}, \boldsymbol{X}_{k, t}\right)
$$

where $\boldsymbol{X}_{k, t}$ is a vector of unexplained factors that affect enrollment and are assumed to create random variation in the dependent variable.

An equivalent specification is used to estimate the effect on college attainment. In this case, the dependent variable is four-year-equivalent degrees earned in public colleges $\left(D_{k, t}\right)$ per potential college graduate, and 
potential college graduates are measured as high school graduates four years earlier $\left(G_{k, t-4}\right)$. As noted above, public funding for tertiary education is not assigned by degree level, hence to best quantify the relationship between funding and degrees requires accounting for all degrees. To do this it is assumed that associate's and master's degrees take two (additional) years of education, while bachelor's, professional, and doctorate degrees average four (additional) years of schooling; thus associate's and master's degrees count as half of a four-year degree. The interpretation of the subsequent estimates is then the weighted average for all levels of postsecondary education (Note 7).

Obviously these degrees are not earned within a fiscal year, thus the independent variable of interest in this case is average state- and local-government appropriations for postsecondary education during the current and previous three years $\left(\sum_{t-3}^{t} S_{k, t} / 4\right)$ per potential college graduate (high school graduate four years earlier). The other control variables are average per capita income during the current and past three years $\left(\sum_{t-3}^{t} I_{k, t} / 4\right)$, the four-year average proportion of the population within the ages of 35 to 64 with at least a bachelor's degree $\left(\sum_{t-3}^{t} A_{k, t} / 4\right)$, and year. There are also controls for fixed effects for each state. Thus, the attainment equation to be estimated is

$$
D_{k, t} / G_{k, t-4}=\mathrm{f}\left(\sum_{t-3}^{t} S_{k, t} / 4 G_{k, t-4}, \sum_{t-3}^{t} I_{k, t} / 4, \sum_{t-3}^{t} A_{k, t} / 4, t, d_{k}, \boldsymbol{X}_{k, t}\right) .
$$

A potentially important complication is that state funding for tertiary education might not be exogenous. Public funding may respond to enrollment [indeed, Bound and Turner (2007)provide evidence of this], thus the observed correlation between enrollment/attainment and state funding is not necessarily the causal effect. That is, it may be the case that the level of state funding for higher education endogenously depends on the level of enrollment (and/or the level of potential college students). Hence, it is not clear what is causing what in an ordinary regression equation. Atwo-stage instrumental variables approach is thus appropriate. Two instruments are used to provide exogenous variation in state funding for postsecondary education per potential student/graduate: state- and local-government tax revenues and primary and secondary education expenditures, both relative to state personal income $\left(V_{k, t} / Y_{k, t}\right.$, where $V$ is tax revenues or K-12 expenditures and $Y$ is state income) (Note 8). Thus, the instrumental-variables equations to estimated are

$$
E_{k, t} / \sum_{s=t-4}^{t-1} G_{k, s}=\mathrm{f}\left[S_{k, t} / \sum_{s=t-4}^{t-1} G_{k, s} \mathrm{~g}\left(V_{k, t} / Y_{k, t}, I_{k, t}, \mathrm{~A}_{k, t}, t, d_{k}, Z_{k, t}\right), I_{k, t}, \mathrm{~A}_{k, t} t, d_{k}, \boldsymbol{X}_{k, t}\right]
$$

and

$$
D_{k, t} / G_{k, t-4}=\mathrm{f}\left[\sum_{t-3}^{t} S_{k, t} / 4 G_{k, t-4} \mathrm{~g}\left(\sum_{t-3}^{t} V_{k, t} \sum_{t-3}^{t} Y_{k, t-4}, \sum_{t-3}^{t} I_{k, t} / 4, \sum_{t-3}^{t} A_{k, t} / 4, t, d_{k}, \boldsymbol{Z}_{k, t}\right), \sum_{t-3}^{t} I_{k, t} / 4, \sum_{t-3}^{t} A_{k, t} / 4, t, d_{k}, \boldsymbol{X}_{k, t}\right],
$$
where $\boldsymbol{Z}_{k, t}$ is a vector of unexplained factors that affect state funding per potential student/graduate.

\section{Data}

The most comprehensive source of information on U.S. state funding for postsecondary education is the State Higher Education Executive Officer's State Higher Education Finance (SHEF) project. To try to estimate the overall impact of public support for postsecondary education, their broadest consistent measure, "Gross State Support" plus "Local Tax Appropriations" less "Research, Agricultural, and Medical Appropriations" (RAM), is used (RAM appropriations are excluded because these data were not consistently collected before 2000). This measure includes all non-RAM state- and local-government appropriations for postsecondary education except for capital construction and debt retirement (these figures are not available).

For comparison purposes, tuition and fee revenue at public colleges are included in some of the regression equations. These data are also taken from the SHEF project, as are the enrollment data. To be consistent with their state funding measure, tuition and fee revenue and enrollment in medical schools are excluded. The FTE enrollment measure is based on credit hours (not head counts) taken by degree- and certificate-seeking students in public postsecondary institutions. Tuition and fee revenue per student is the weighted average net price of attending public colleges in a state in a year, not the "sticker" price.

Degrees from state colleges are calculated from merging the annual Completions and Institutional Characteristics files of the Integrated Postsecondary Education Data System from the National Center for Education Statistics. These institutional-level data are aggregated into totals for each state for each academic year from 1985 onwards (and degrees are sorted into associate's, bachelor's, master's, professional, and doctorate). To be consistent with the state funding and enrollment measures, medical degrees are excluded. Degrees earned in Washington, DC and from U.S. military colleges are also excluded.

Data on states' high school graduates are available from various years of the National Center for Education Statistics'Digest of Education Statistics. Data on graduates from private high schools, however, are incomplete (while data on graduates from public high schools are complete for all years used here). There is an 11-year gap in the estimates of private high school graduates from 1981 through 1991, followed by a two-year gap in 1993 
and 1994, and single instances of missing information in even years since 1996. Thus, missing observations are imputed using interpolation. Given that slightly less than 10 percent of total high school graduates have been from private high schools since 1976 and that this proportion has been steady, the measurement error from this interpolation is likely to be quite small (Note 9).

The most consistent source for interstate data on state- and local-government revenues and expenditures is the U.S. Census Bureau's State and Local Government Finances. Data on state personal income are from the Bureau of Economic Analysis (third- and fourth-quarter-calendar measures from the previous year are combined with first-and second-quarter measures of the year in question to make annual income consistent with academic years). The percentage of the state's population within the ages of 35 to 64 with at least a bachelor's degree is calculated using theCensus Bureau's Current Population SurveyOutgoing Rotations Groups (Note 10). All dollar values are converted to December 2005 values (i.e., academic year 2006) using the Bureau of Labor Statistics' Consumer Price Index.

\section{Results}

Table 1 shows the estimated coefficients in the enrollment and degree equations using ordinary least squares (OLS). The baseline cases are the left-side columns. As expected, the enrollment rate (enrollment per potential college student) and the degree rate (four-year equivalent degrees per potential college graduate) are positively related to state support for postsecondary education, average bachelor's degree attainment, and time. Curiously, the enrollment and degree rates are negatively related to per capita income in the multivariate regression (although, as expected, the univariate correlation between the enrollment/degree rate and income is strongly positive). Although the negative multivariate relationship between per capita income and the enrollment/degree rate is unexpected, it is not completely implausible for two reasons. First, per capita income is partly picking up differences in real costs of living (i.e., per capita income is generally higher where the cost of living is higher). Other things equal, the real value of dollars of state support for postsecondary education is lower in states with relatively high costs of living. Second, higher incomes to some extent probably lead to relatively more students attending private collegesinstead of public colleges.

Table 1. Linear OLS Regressions

\begin{tabular}{|c|c|c|c|c|c|c|}
\hline \multirow[b]{2}{*}{ State Support } & \multicolumn{3}{|c|}{ College Enrollment } & \multicolumn{3}{|c|}{ Degree Attainment } \\
\hline & 0.588 & & 0.597 & 0.389 & & 0.411 \\
\hline & 0.028 & & 0.029 & 0.018 & & 0.019 \\
\hline \multirow[t]{2}{*}{ Tuition \& Fees } & & -0.204 & 0.037 & & -0.061 & 0.101 \\
\hline & & 0.045 & 0.034 & & 0.035 & 0.026 \\
\hline \multirow[t]{2}{*}{ Per Capita Income } & -0.240 & -0.144 & -0.242 & -0.153 & -0.079 & -0.159 \\
\hline & 0.013 & 0.020 & 0.013 & 0.009 & 0.012 & 0.009 \\
\hline \multirow[t]{2}{*}{ Parental Degree Attainment } & 0.583 & 0.881 & 0.558 & 0.579 & 0.787 & 0.466 \\
\hline & 0.108 & 0.128 & 0.112 & 0.082 & 0.105 & 0.090 \\
\hline \multirow[t]{2}{*}{ Trend } & 0.013 & 0.013 & 0.013 & 0.009 & 0.008 & 0.009 \\
\hline & 0.001 & 0.001 & 0.001 & 0.000 & 0.001 & 0.000 \\
\hline Regression F & 380.0 & 323.6 & 372.7 & 334.3 & 230.4 & 343.5 \\
\hline
\end{tabular}

Robust standard errors are in italics. There are also unreported controls for each state. State support, tuition and fees, and per capita income are in ten thousands of 2006 dollars.

The coefficients of interest are the ones for state support for higher education. The baseline cases in Table 1 show that an additional $\$ 1,000$ (in AY 2006 dollars) of public funding per potential college student/graduate is associated with a 5.9 percentage-point increase in the enrollment rate and a 3.9 percentage-point increase in the degree rate.These coefficient estimates compared to the sample-mean enrollment and degree rates $(0.761$ and 0.440 , respectively) suggest that an additional $\$ 1,000$ of state funding per potential student/graduate is associated with a 7.7 percent increase in the enrollment rate and an 8.8 percent increase in the degree rate. The enrollment 
elasticity with respect to state support (an "elasticity" measures the percentage change in the dependent variable relative to the percentage change in the independent variable) evaluated at the sample means of the enrollment rate and state support per potential student $(\$ 4,939)$ is 0.38 . The degree elasticity with respect to state support evaluated at the sample means of the degree rate and annual state support per potential graduate is 0.43 .

Direct estimates of the elasticities are reported Table 2. The natural logarithm of all the variables (except for year) is used to provide direct estimates of the proportionate effects. The results are essentially the same as in the linear specification. The baseline enrollment and degree elasticities are 0.37 and 0.45 , respectively - roughly the same as from the linear estimates evaluated at the sample means.

Table 2. Logarithmic OLS Regressions

\begin{tabular}{|c|c|c|c|c|c|c|}
\hline \multirow[b]{2}{*}{$\ln$ (State Support) } & \multicolumn{3}{|c|}{$\ln ($ College Enrollment $)$} & \multicolumn{3}{|c|}{$\ln$ (Degree Attainment) } \\
\hline & 0.367 & & 0.369 & 0.454 & & 0.469 \\
\hline & 0.019 & & 0.019 & 0.022 & & 0.022 \\
\hline \multirow[t]{2}{*}{$\ln$ (Tuition \& Fees) } & & -0.060 & 0.008 & & 0.004 & 0.071 \\
\hline & & 0.018 & 0.014 & & 0.022 & 0.016 \\
\hline \multirow[t]{2}{*}{$\ln ($ Per Capita Income) } & -0.643 & -0.337 & -0.641 & -0.809 & -0.272 & -0.802 \\
\hline & 0.057 & 0.077 & 0.057 & 0.069 & 0.078 & 0.070 \\
\hline \multirow[t]{2}{*}{ ln(Parental Degree Attainment) } & 0.297 & 0.475 & 0.295 & 0.315 & 0.594 & 0.288 \\
\hline & 0.034 & 0.035 & 0.034 & 0.040 & 0.040 & 0.041 \\
\hline \multirow[t]{2}{*}{ Trend } & 0.012 & 0.010 & 0.011 & 0.017 & 0.011 & 0.015 \\
\hline & 0.001 & 0.002 & 0.001 & 0.001 & 0.002 & 0.001 \\
\hline Regression F & 419.8 & 257.6 & 416.4 & 322.1 & 200.4 & 335.3 \\
\hline
\end{tabular}

Robust standard errors are in italics. There are also unreported controls for each state.

For comparison, state support per potential student is replaced in the regression equations with average net tuition and fees per student at state collegesin the middle columns of Tables 1 and 2 . The average net price of public colleges has a negative effect on the enrollment/degree rate, as expected. But the coefficients are much smaller, and the standard errors are relatively much larger, for tuition than for public support (keeping in mind that both tuition revenue and FTE enrollment are likely to endogenously depend on state support for postsecondary education). The estimated linear tuition coefficient in Table 1 is 2.9 times smaller in the case of enrollment and 6.4 times smaller in the case of degrees. Moreover, the magnitudes of the differences are larger still in terms of elasticities because the average price of public college $(\$ 3,172)$ is less than average state support per potential student. The enrollment and degree elasticities with respect to student price, -0.09 and -0.04 respectively (-0.06 and 0.00 , and not statistically significant when estimated directly), are 4.5 and 10.2 times smaller than their elasticities with respect to state support.

The right-side columns of Tables 1 and 2 include both state support per potential student and tuition and fees per student as explanatory variables. Including the net price of public college education essentially has no impact on the coefficient on state support. Moreover, the coefficient on tuition has an unanticipated positive sign when also controlling for state support, although it is small and not statistically different from zero in the enrollment regressions. Evidently the multicollinearity between state support and net price (the correlation coefficient between annual state support per potential student and annual net tuition revenue per student is -0.37 , and -0.33 between their four-year moving averages)is such that net price does not deter college enrollment and attainment when controlling for state support.

The OLS regression equations suggest that public support for higher education has a strong effect on college enrollment and attainment. But, as noted earlier, the observed correlation does not necessarily measure the causal effect. State support for higher education may respond endogenously to the number of students attending college. Thus, the preferred set of estimates is from the two-stage instrumental variables approach (IV). In addition to addressing potential endogeneity bias, the IV estimates also eliminate the potential division bias noted earlier. Three sets of IV estimates corresponding to the baseline OLS estimates (i.e., the left-side columns of Table 1) are reported in Table 3. The strongest instrument for state funding per potential student/graduate is state- and 
local-government tax revenues as a percentage of state income. Although this appears to be a good instrument, a second instrument is also used so that both state support and tuition can be simultaneously instrumented later. Thus, results are also presented when using state- and local-government primary and secondary education expenditures as a percentage of state income as the instrument, and when using both variables as instruments.

Table 3. Linear IV Regressions

\begin{tabular}{|c|c|c|c|c|c|c|}
\hline & \multicolumn{3}{|c|}{ College Enrollment } & \multicolumn{3}{|c|}{ Degree Attainment } \\
\hline Instrument & Taxes & $\mathrm{K}-12$ & Both & Taxes & $\mathrm{K}-12$ & Both \\
\hline \multirow[t]{2}{*}{ State Support } & 0.543 & 0.640 & 0.551 & 0.322 & 0.254 & 0.320 \\
\hline & 0.064 & 0.126 & 0.063 & 0.024 & 0.066 & 0.024 \\
\hline \multirow[t]{2}{*}{ Per Capita Income } & -0.233 & -0.248 & -0.234 & -0.140 & -0.127 & -0.140 \\
\hline & 0.016 & 0.024 & 0.016 & 0.010 & 0.015 & 0.010 \\
\hline \multirow[t]{2}{*}{ Parental Degree Attainment } & 0.597 & 0.567 & 0.594 & 0.604 & 0.629 & 0.605 \\
\hline & 0.109 & 0.114 & 0.109 & 0.081 & 0.087 & 0.081 \\
\hline \multirow[t]{2}{*}{ Trend } & 0.013 & 0.013 & 0.013 & 0.009 & 0.009 & 0.009 \\
\hline & 0.001 & 0.001 & 0.001 & 0.000 & 0.000 & 0.000 \\
\hline Regression F & 378.6 & 367.9 & 378.3 & 311.0 & 306.4 & 311.0 \\
\hline 1st-Stage Exclusion F-test & 125.25 & 27.67 & 60.05 & 107.40 & 37.55 & 53.95 \\
\hline 2nd-Stage Exclusion F-test & 0.15 & 0.03 & 0.23 & 1.21 & 0.54 & 0.60 \\
\hline
\end{tabular}

Robust standard errors are in italics. There are also unreported controls for each state. State support and per capita income are in ten thousands of 2006 dollars.

These variables appear to be excellent instruments for providing exogenous variation in state support for higher education. The correlation between the instruments and state support is strong, providing well-identified first-stage regressions to generate predicted values of state funding per potential student/graduate for the second-stage regressions. As shown at the bottom of Table 3, the F-tests ( $\mathrm{t}^{2}$ when there is only one instrument) of the exclusion of the instrument(s) in the first-stage regressions are strongly rejected (Note 11). Moreover, the instruments evidently are not independently correlated with the dependent variable. The F-tests of the exclusion of the instrument(s) in the second-stage regressions are not close to being rejected.

Despite using strong instruments for state support for postsecondary education, none of the IV coefficients in Table 3 are statistically different from their OLS counterparts in the left columns on Table 1. The IV estimates of the effect of state support on enrollment and degree attainment are generally slightly lower than the OLS estimates, although the differences are not statistically significant. The IV results when using tax revenues as the instrument indicate that $\$ 1,000$ of public funding per potential college student/graduate is associated with a 5.4 percentage-point increase in the enrollment rate and a 3.2 percentage-point increase in the degree rate. The state-support elasticities (evaluated at the sample means) of both college enrollmentand degree attainment are 0.35 . When estimating the elasticities directly by expressing the variables (including the instruments) in natural logarithms, the state-support elasticity of enrollment is 0.46 and the state-support elasticity of degrees is 0.38 .

If state support may be endogenous, then tuition may be as well. Thus, Table 4 reports IV estimates when including net tuition and fees as an instrumented control variable. These two IV cases reported in Table 4 correspond to the OLS estimates reported in the middle and right columns of Table 1. As before, none of the coefficients in the equations that include state support are statistically different from their OLS counterparts. But in these instances the instruments do not appear to provide well-identified first-stage regressions to generate predicted values of net tuition for the second-stage regressions, particularly in the case of enrollment (the first-stage exclusion F-test is rejected with only 93.0 percent confidence). Moreover, when (instrumented) state support is not included in the regressions, the F-tests of the exclusion of the instruments in the second-stage regressions are strongly rejected (but this does not occur when state support is included in the regressions). Evidently, in these cases the instruments are correlated with enrollment/attainment through their correlations with state support. Thus, the estimates of the effect of net tuition without controlling for state support are 
probably statistically biased and highly suspect.

Table 4. Linear IV Regressions Including Tuition and Fees

\begin{tabular}{|c|c|c|c|c|}
\hline & \multicolumn{2}{|c|}{ College Enrollment } & \multicolumn{2}{|c|}{ Degree Attainment } \\
\hline \multirow[t]{2}{*}{ State Support } & 0.588 & & 0.256 & \\
\hline & 0.088 & & 0.073 & \\
\hline \multirow[t]{2}{*}{ Tuition \& Fees } & 0.566 & -2.360 & -0.407 & -1.592 \\
\hline & 0.779 & 1.237 & 0.401 & 0.383 \\
\hline \multirow[t]{2}{*}{ Per Capita Income } & -0.246 & -0.119 & -0.119 & -0.047 \\
\hline & 0.025 & 0.038 & 0.023 & 0.023 \\
\hline \multirow[t]{2}{*}{ Parental Degree Attainment } & 0.250 & 2.150 & 1.049 & 2.367 \\
\hline & 0.487 & 0.754 & 0.461 & 0.415 \\
\hline \multirow[t]{2}{*}{ Trend } & 0.010 & 0.026 & 0.010 & 0.013 \\
\hline & 0.005 & 0.008 & 0.001 & 0.002 \\
\hline Regression F & 250.9 & 52.0 & 197.2 & 230.4 \\
\hline 1st-Stage Exclusion F-test & & 2.67 & & 7.51 \\
\hline 2nd-Stage Exclusion F-test & 0.24 & 6.99 & 0.65 & 12.67 \\
\hline
\end{tabular}

Robust standard errors are in italics. There are also unreported controls for each state. State support, tuition and fees, and per capita income are in ten thousands of 2006 dollars.

It is interesting to compare the results found here to the previous literature. The estimated elasticities of public support on enrollment and degree attainment found here are considerably smaller than (specifically, between one half and one third of) the responses implied in Bound and Tuner (2007). The estimated enrollment response to public support using IV is slightly smaller than the estimate in Berger and Kostal (2002). Their estimate is 6.3 percentage points per $\$ 1,000$ in 2004 dollars, compared to 5.4 percentage points found here. Berger and Kostal, however, do not attempt to account for the potential endogeneity of public support (or potential division bias), and the estimated OLS correlation found here (5.9 percentage points) is about the same as their estimate.

The estimated effect of state support on enrollment found here is generally of a similar magnitude to the estimated effect of college price found in the literature. To be more specific, the effect of public support found here is smaller (in absolute value) than the effect of college price generally found in most of the early literature, but somewhat larger than generally found in the recent literature (Note 12). The implied range of the price elasticity of enrollment in Leslie and Brinkman's (1987) survey of this literature is -0.5 to -0.8 , compared to a state-support elasticity of 0.35 found here. However, the early literature on the student response to tuition did not account for potential endogeneity bias. Deming and Dynarski's (2009) survey of the recent literaturequantifying the effects of various financial-aid programs indicates that estimates of the enrollment response to net price center around 4 percentage points per $\$ 1,000$ of net tuition (in 2004 dollars), compared to the enrollment response to state support of 5.4 percentage points found here.

\section{Conclusion}

College attainment is not the only goal from public investment in tertiary education, but is almost certainly the main one. Moreover, tertiary education is one of the larger categories of public spending, but there is essentially no direct evidence on the amount of additional college attainment bought with this expenditure. Studies that estimate the effect of net tuition on college attendance are informative about this important policy question, but are not sufficient because state funding for higher education and college price evidently are not inversely proportionate. State support for higher education also affects resources per student, and decisions about college attendance are about value, not just price. Thus, state support can affect college attendance and completion without necessarily affecting the net price, and estimates of the tuition response are not necessarily the same as the response to state funding. And perhaps the more pertinent policy question is about the student response to public funding.

This study examines U.S. state-level data from 1985 through 2006 to try to answer this question. The effects of 
public support are estimated for both college enrollment and degree attainment. To deal with the possibility that state funding for tertiary education may endogenously depend on enrollment, these effects are estimated using two-stage instrumental variables. To estimate the causal effect of state postsecondary education spending on college enrollment and degree attainment, state- and local-government tax revenues and K-12 expenditures are used as instruments for state funding for postsecondary education. The results confirm the notion that state funding for higher education leads to greater college attainment. State funding for higher education was shown to have significant causal effects on both college enrollment and degree attainment. Moreover, the results suggest that the effect of public funding is somewhat greater than the effect of college price.

There are numerous avenues for corroborating, building upon, and extending this research. For instance, an important unanswered policy question is quantifying the extent that additional college attainment at state colleges from public support comes from reduced college attainment at private colleges. Indeed, Peltzman (1973) suggests that public higher education crowds out private college education substantially. Similarly, it is important to quantify the extent that the results shown here are due to bringing more students into college nationally versus retaining/drawing students in/to a state. Another interesting avenue for additional study is disentangling the total effect on college attainment into the part due to attracting students into postsecondary education from the part due to improving persistence.

\section{Acknowledgements}

I am grateful to Wisconsin Center for the Advancement of Postsecondary Education research assistants Tora

Frank, Effendy Liejanto, and Justin Ronca for their contributions to this project.

\section{References}

Berger, M. C., \& Kostal, T. (2002). Financial resources, regulation, and enrollment in US public higher education. Economics of Education Review, 21, 101-10. http://dx.doi.org/10.1016/S0272-7757(00)00065-0

Blose, G. L., Porter, J. D., \& Kokkelenberg, E. C. (2006). The effect of institutional funding cuts on baccalaureate graduation rates in public higher education. In R. G. Ehrenberg (Ed.), What's happening to public higher education? (ACE/Praeger series on higher education). Washington, DC: Praeger Publishers.

Borjas, G. J. (1980). The relationship between wages and weekly hours of work: The role of division bias. Journal of Human Resources, 15, 409-23. http://dx.doi.org/10.2307/145291

Bound, J., \& Turner, S. (2007). Cohort crowding: How resources affect collegiate attainment. Journal of Public Economics, 91, 877-99. http://dx.doi.org/10.1016/j.jpubeco.2006.07.006

Chevalier, A., Harmon, C., Walker, I., \& Zhu, Y. (2004). Does education raise productivity, or just reflect it? Economic Journal, 114, 499-517. http://dx.doi.org/10.1111/j.1468-0297.2004.00256.x

Delaney, J. A., \& Doyle, W. R. (2011). State spending on higher education: Testing the balance wheel over time. Journal of Education Finance, 36(4), 343-368.

Deming, D., \& Dynarski, S. (2009). Into college, out of poverty? Policies to increase the postsecondary attainment of the poor. National Bureau of Economic Research Working Paper No. 15387.

Groot, W., \& Oosterbeek, H. (1994). Earnings effects of different components of schooling: Human capital versus screening. Review of Economics and Statistics, 76(2), 317-321. http://dx.doi.org/10.2307/2109885

Heller, D. E. (1997). Student price response in higher education: An update to Leslie and Brinkman. Journal of Higher Education, 68(6), 624-59. http://dx.doi.org/10.2307/2959966

Hovey, H. A. (1999). State spending for higher education in the next decade: The battle to sustain current support. San Jose, CA: National Center for Public Policy and Higher Education.

Kane, T. J., Orszag, P., \& Apostolov, E. (2005). Higher education appropriations and public universities: Role of Medicaid and the business cycle. Brookings-Wharton Papers on Urban Affairs. http://dx.doi.org/10.1353/urb.2006.0008

Kelly, P. J., \& Jones, D. P. (December 2005). A new look at the institutional component of higher education finance: A guide for evaluating performance relative to financial resources. Boulder, CO: National Center for Higher Education Management Systems.

Koshal, R. K., \& Koshal, M. (2000). State appropriation and higher education tuition: What is the relationship? Education Economics, 8(1), 81-9. http://dx.doi.org/10.1080/096452900110319

Leslie, L. L., \& Brinkman, P. T. (1987). Student price response in higher education: The student demand studies. 
Journal of Higher Education, 58(2), 181-204. http://dx.doi.org/10.2307/1981241

Peltzman, S. (1973). The effect of government subsidies-in-kind on private expenditures: The case of higher education. Journal of Political Economy, 81(1), 1-27. http://dx.doi.org/10.1086/260004

Rizzo, M. J. (2006). State preferences for higher education spending: A panel data analysis, 1977-2001. In R. G. Ehrenberg (Eds.), What's Happening to Public Higher Education?. Westport, CT: Praeger.

Ryan, J. F. (2004). The relationship between institutional expenditures and degree attainment at baccalaureate $\begin{array}{lllll}\text { colleges. } & \text { Research in Higher }\end{array}$ http://dx.doi.org/10.1023/B:RIHE.0000015691.02545.61

Titus, M. A. (2009). The production of bachelor's degrees and financial aspects of state higher education policy: A dynamic analysis. Journal of Higher Education, 80(4), 439-68. http://dx.doi.org/10.1353/jhe.0.0055

Titus, M. A., Simone, S., \& Gupta, A. (2010). Investigating state appropriations and net tuition revenue for public higher education: A vector errorcorrection modeling approach. Houston, TX: Institute for Higher Education Law and Governance Institute Monograph 09-05.

Trostel, P. A., \& Ronca, J. M. (2009). A simple unifying measure of state support for postsecondary education.Research in Higher Education, 50(3), 215-47. http://dx.doi.org/10.1007/s11162-008-9115-6

Zhang, L. (2009). Does state funding affect graduation rates at public four-year colleges and universities?. Educational Policy, 23(5), 714-31. http://dx.doi.org/10.1177/0895904808321270

\section{Notes}

Note 1. Ryan (2004), Blose et al. (2006), Titus (2009), and Zhang (2009) are also relevant here. These studies explore the related issue of the extent that public funding for higher education affects college completion rates (but not the extent that it affects enrollment, and thus not the extent that it affects attainment). Also, Kelly and Jones (2005) and Trostel and Ronca (2009) have, among other things, very basic analyses of the relationship between state funding for postsecondary education and degree attainment.

Note 2. Specifically, Bound and Turner find that exogenous increases in the number of potential college graduates in a state (18 year olds in a state four years earlier) increases state funding for higher education by about only about 60 percent of the increase in the number of potential college students (i.e., funding per student falls by 40 percent), and it also decreases the number of bachelor's degrees awarded relative to the number of potential college graduates in the state by roughly 40 percent. Thus, the natural experiment created through changes in cohort sizes indicates that bachelor's degree attainment in a state changes roughly in proportion to state funding per potential college graduate.

Note 3. This is the issue of whether education produces human capital or is a signaling/screening mechanism. Although there is some evidence that obtaining degrees has labor-market effects independent of years in college, the evidence that it is time spent in education that matters is more compelling. On this issue see, e.g., Groot and Oosterbeek (1994) and Chevalier et al. (2004).

Note 4. Berger and Kostal (2002) have enrollment relative to estimates of the population within the ages of 18 to 24. Bound and Turner (2007) have bachelor's degrees relative to estimates of the population 18 years old four years earlier. For two reasons, however, the number of high school graduates should be a better measure of potential college students. The number of high school graduates is a better measure of those ready to go on to college. And estimates of the number of high school graduates are probably much more precise than population estimates that are largely interpolated between census years.

Note 5. See data in Tables 207 and 208 of the National Center for Education Statistics'Digest of Education Statistics: 2006. Also see Trostel and Ronca (2009) for further justification for using high school graduates in the preceding four years as the measure of potential enrollment.

Note 6. Berger and Kostal (2002) analyze undergraduate enrollment only. Bound and Turner (2007) analyze attainment of bachelor's degrees only, as well as the case of enrollment (presumably both undergraduate and graduate).

Note 7. Of total non-medical four-year-equivalent degrees awarded by U.S. public institutions from 1985 through 2006, 67.5 percent are bachelor's degrees, 19.0 percent are associate's degrees, 9.7 percent are master's degrees, and 3.8 percent are professional and doctorate degrees.

Note 8. Total, general, and own state- and local-government revenues as well as total and direct state- and local-government expenditures were also considered as instruments for state support for higher education. Per 
capita revenues and expenditures were also considered instead of these being relative to state income.In addition, following recent work [e.g., Hovey (1999), Kane et al. (2005), Rizzo (2006), Titus (2009), and Delaney and Doyle (2011)] showing that state expenditures on welfare, corrections, and K-12 education crowd out funding for higher education, these measures and their sum (as well as their percentages of total state- and local-government expenditures) were considered too. The two instruments selected were the ones on the revenue and expenditure sides providing the strongest explanatory power for state funding for postsecondary education per potential student/graduate. The results were very similar when using the different instrumental variables that had close to the same degree of explanatory power for the potentially endogenous variable.

Note 9. As alluded to earlier, the measurement error in total high graduates in each state is likely to much less than estimates of state college-age populations. Moreover, this may be important because measurement error in the potential number of college students will create "division bias" (see Borjas, 1980) in the coefficient estimate for state support for postsecondary education. That is, because both the dependent and independent variables are divided by the same factor, measurement error in this factor will create a correlation between the variables and create an upward bias in the coefficient estimate.

Note 10 . To be more specific, the college-attainment proportions are calculated weighting the observations by their sampling weights. Prior to 1992 education was measured in years of schooling rather than credential attainment, but this measurement change apparently makes little difference in the case of bachelor's degrees. College attainment before 1992 is counted as 16 or more years of education. There is no noticeable break in the data from the measurement change. The measure of parental college attainment is converted from calendar years to academic years using interpolation.

Note 11. The correlation coefficient between annual state support and annual tax revenues is 0.44 , and 0.33 between annual state support and annual K-12 expenditures ( 0.49 and 0.38 , respectively for their four-year moving averages). The correlation coefficient between annual tax revenues and annual K-12 spending is 0.60 ( 0.65 for their four-year moving averages).

Note 12. Moreover, the recent research generally focuses on targeted programs laced with incentives, and presumably the student price response to these programs targeted toward students on the margin of college attendance is greater than the overall average response. 